\title{
ЗНАЧЕНИЕ КАЛОРИЙНОСТИ ПРИЕМОВ ПИЩИ В ФОРМИРОВАНИИ ИЗБЫТОЧНОГО ВЕСА И ОЖИРЕНИЯ У ДЕТЕЙ И ПОДРОСТКОВ
}

\author{
Волкова Л.Ю.
}

ФГБУ «Национальный медицинский исследовательский институт терапии и профилактической медицины», Москва

ЦЕЛЬ: целью исследования стал анализ калорийности отдельных приемов пищи у детей с избыточной массой тела и ожирением.

МАТЕРИАЛЫ И МЕТОДЫ: исследование проведено в период с 2012 по 2015 гг. на базе амбулаторно-поликлинического учреждения г. Москвы. В исследование было включено 65 детей и подростков в возрасте от 7 до 17 лет, имеющих избыточную массу тела и ожирение. Оценка фактического питания проведена метолом 7-ми дневной регистрации потребляемой пищи. Параметры пищевого статуса (антропометрические показатели) измерены в соответствие международными и отечественными рекомендациями. Полученные антропометрические данные были проанализированы с помощью стандартов центильных распределений и метода z-скор Всемирной Организации здравоохранения.

PЕзУЛЬТАТЫ: анализ режима питания у обследованных детей с избыточной массой тела и ожирением позволил установить следующие факты. Значимое влияние на степень избыточного веса и выраженность ожирения оказывает распределение энергии по приемам пищи. В изученной группе детей прием пищи «завтрак», в среднем, обеспечивает 21\% суточной калорийности рациона, что находится в пределах рекомендуемой нормы. Выявлена слабая отрицательная корреляционная связь ( $r=-0.27)$ между долей завтрака по калорийности и степенью избыточного веса. Т.е. чем меньше энергия пищи, получаемой за счет завтрака, тем выше степень ожирения у ребенка. Прием пищи «второй завтрак» обеспечивает 14\% суточной калорийности рациона, что почти в 1,5 раза выше рекомендуемой нормы. Прием пищи «обед» обеспечивает 28\% суточной калорийности рациона, что несколько ниже рекомендованной нормы. Прием пищи «полдник» обеспечивает 28\% суточной калорийности рациона, что превышает рекомендованную норму в 2,8 раза. Прием пищи «ужин» обеспечивает 33,6\% суточной калорийности рациона, что превышает рекомендованную норму в 1,3 раза. Наблюдается сдвиг основной калорийности рациона на вечерние часы. В среднем, суммарная доля энергии полдника и ужина составляет 69,2\%, что почти вдвое превышает рекомендованную норму. Выявлена слабая положительная корреляционная связь (к=0,26) между долей ужина по калорийности и степенью избыточного веса. Т.о. чем выше энергия пищи, получаемой за счет ужина, тем выше степень ожирения у ребенка. Большее значение высокая доля калорийности вечерних приемов пищи (полдника и ужина) имеет для степени ожирения у мальчиков $(r=0,40)$, чем у девочек $(r=0.34)$. Чем старше ребенок, тем сильнее соответствие между избыточной калорийностью вечерних приемов пищи и степенью избыточного веса. Интерпретация данной зависимости может свидетельствовать о том, что чем дольше «стаж» нарушенного режима питания у ребенка, тем значительнее степень ожирения. Среди всех изученных факторов, наибольшую связь со степенью ожирения имеет режим питания, при котором преобладают вечерние приемы пищи. Выявленные особенности режима питания у детей в возрасте 7-17 лет, имеющих избыточную массу тела и ожирение, имеют значение для разработки рекомендаций при подборе как групповых, так и персонифицированных программы коррекции веса. 